回収自己血輸血を行った巨大副腎外褐色細胞腫の 1 例

\author{
島根県立中央病院外科 \\ 中 村 健一徳家敦夫尾崎信弘
}

巨大蝎色細胞腫手術の際には術中の出血, 血圧変動への対処が必要となる. 症例は51 藏, 男性. 15年前より高血圧, 心房細動を指摘されていたが検診のエコーで腹腔内腫箵 を指摘され, 副腎外巨大蝎色細胞腫と診断きれた。腫㾤摘出尃, 右腎合併切除を施行。 出血量4,986ccであったが回収自己血輸血装置により2,100cc 返血した。返血は腫瑒摘出 前より開始したが，腫瘍摘出前に血圧の変動が大きかったのに比へ，摘出後は自己血翰 血を継続しても極めて安定した循環動態を示した。切除標本は $13 \cdot 7.2 \times 5 \mathrm{~cm}$ の境界明 瞭な腫揚で悪性所見は認めら机なかった。褐色細胞腫摘出術に際しての回収自己血翰血 は回収自己血中のカテコラミンによる血圧上昇が危惧されるが，注意深く血圧をモ二夕 一し, 術前のドーパミン值に留意することで安全に施行可能であると考えられた。

索引用語：蝎色細胞腫，副腎外，自己血輸血

はじめに

褐色細胞腫の術中管理では血中カテコラミン濃度の 変動に上る循環動態のコントロールが要求されると同 時に，腫盷が巨大な場合には術中大量出血への対処も 必要である。今回巨大副筲外褐色細胞腫に対し回収自 己血輸血を行い，同種血輸血を回避しえた症例を経験 したので報告する。

症例

症例：51歲, 男性.

主訴：高血压.

現病歴：1988年より高血压，心房細動を指摘きれ 1991年からは近医で降圧剂などの内服加療を受けてい た. 2003 年 4 月21日ドックて腹部超音波検查施行の際 に, 右副腎腫瘍, 右水腎症を指摘され当院受診。

家族歴：特記すべきことなし。

既往歴：上記以外飞特記事項なし。

初診時現症: 身長 $173 \mathrm{~cm}$, 体重 $69 \mathrm{~kg}$. 血圧 $180 / 110$ $\mathrm{mmHg}$. 脈拍 $60 /$ 分, 不整. 右上腹部に約 $10 \mathrm{~cm}$ の巨大 な腫瘤を触知した。

入院時血液検查: WBC $9,100 / \mu \mathrm{l}, \mathrm{RBC} 471 \times 10^{4} /$ $\mu \mathrm{l}$, Hb $15.7 \mathrm{~g} / \mathrm{dl}$, Het $45.5^{\circ}{ }^{\circ}$, PLT $29.8 \times 10^{4} / \mu \mathrm{l}$ て

2003年12月 1 日受付 2004 年2月4日採用 〈所属施設住所〉

厂693-8555 出雲市姫原町 4-1-1
軽度の白血球增加のほか異常を認めなかった．生化学 検査では Cre $1.15 \mathrm{mg} / \mathrm{dl}$ と軽度高值を認めたほかは 肝機能, 電解質に異常を認めなかった。Creは軽度高值 であったが Ccr は $120 \mathrm{ml} /$ 分と基準値内であった。血糖 值は随時血糖 $118 \mathrm{mg} / \mathrm{dl}, \mathrm{HbAlc} 5.1)^{\circ} \%$ と耐糖能異常は 認めなかった. CEA は $12.8 \mathrm{ng} / \mathrm{ml}$ と高值を示した。

内分泌学的唡査: 血中アドレナリンは $0.13 \mathrm{ng} / \mathrm{ml}$ と正常範囲内であったが,ノルアドレナリン4.0ng $/ \mathrm{ml}$ (基準徂 : 0.15 0.5T)，ドーパミン0.18ng/ml $(0$ 〜0.03）と高值を示した．血中アルドステロンおよび コルチゾールは基準值内であった，尿中のカテコラミ ン排泄量はアドレナリン $43.9 \mu \mathrm{g} / \mathrm{day}(1 \sim 23)$, ノルア ドレナリン $2,110 \mu \mathrm{g} / \mathrm{day}(29 \sim 120)$, ドーパミン 5,000 $\mu \mathrm{g} /$ day $(100 \sim 1,000)$ といずれも高值を認めた。

安静時心常図: 心房細動, 脈拍 61 .

腹部造影 CT, MRI : 右㻉門部に $13 \times 9 \times 8 \mathrm{~cm}$ の腫 惶を認めた。中心部は不均一で边緑が強く造影効果を 受けていた，腫愓は右腎静脈と下大静脈を腹側に圧排 しておりり右腎動脈は腫場の背側を走行していた（図 1).右副腎は腫嚗とは別の部位に描出されており副腎 外の病変と思われた。また，右水腎症を生じており右 腎実質の造影効果はやや遈延していた。

$I^{131}-$ MIBG シンチグラフィー：右腎門部の腫瘍に 一致して強い集積を認めた。

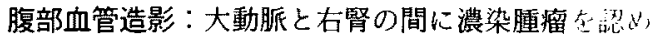




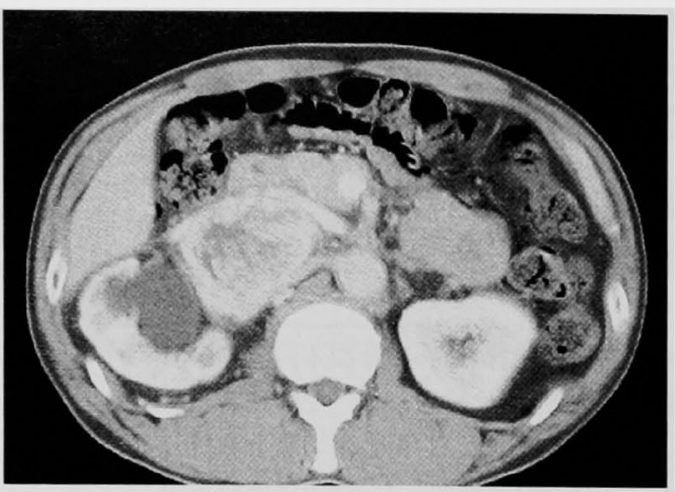

図 1 腹部造影 $\mathbf{C T}$ ：右腎門部に $13 \cdot 9 \times 8 \mathrm{~cm}$ の腫瘍を 認めた。腫瘍は右腎静脈と下大静脈を腹側に圧排してお り右監動脈は腫㾨の背側を走行していた，右腎は水腎症 をきたしてた。

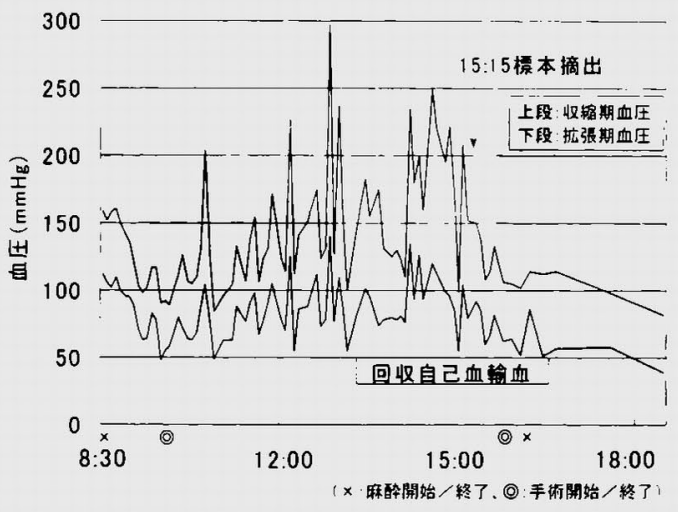

図２術中経過：腫湟摘出前は自己血輸血の有無に関わ らず間久的に収縮期血圧.200 $\mathrm{mmHg}$ 以上を示した。腫瘍 摘出後は自己血輸血を稞続しつつ収縮期血圧 $80 〜 150$ $\mathrm{mmHg}$ の間て安定した循環動態を示した。

た. 大動脈からの直接の枝に加え右腎動脈および腎門 部からの多数の枝に上り腫敀は栄養されていた, Late phaseては右腎静脈が造影されなかった，下大静脈造 影では下大静脈は腫瘍により左側に圧排されていたが 壁不整は認められなかった。

手術所見：後腹膜異所性褐色細胞腫と診断し2003年 6 月12日褐色細胞腫摘出術, 右腎合併切除を施行した. 逆 $\mathrm{T}$ 字型切開で開腹. 腫瘍は腹側の下大静脈, 右腎静 脈, 背側の右腎動脈, 右背側の右腎, 左側の大動脈に 讲まれるように存在していた。 下大静脈は左頭側へ圧 排されていたが腫崵の浸潤は認められなかった，腫湟 への栄養血管が右腎動脈, 腎門部より多数分枝してい

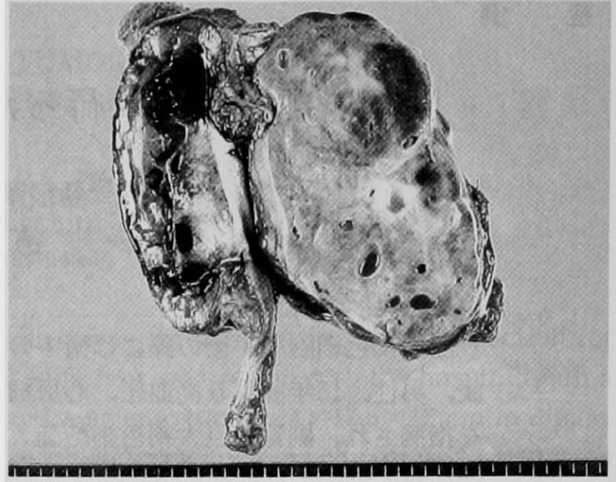

図 3 摘出標本所見：右腎内側に接して $13 \times 7.2 \times$ $5 \mathrm{~cm}, 270 \mathrm{~g}$ の境界明瞭な充実性腫崵が存在した.

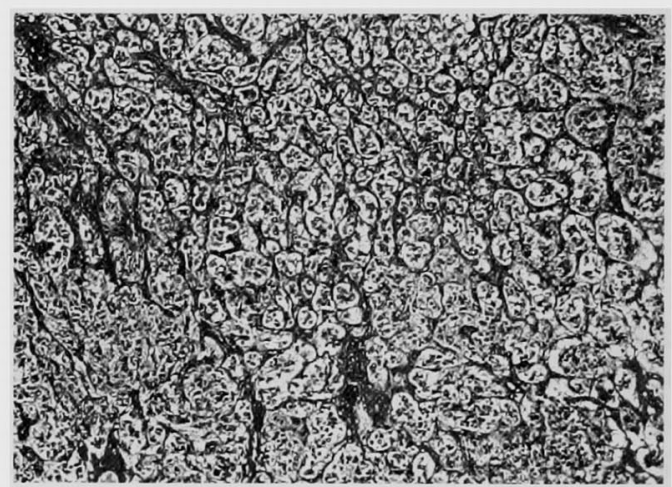

図4病理組織所見（HE 杂色, $\times 200)$ ：腫瘍組織は胞宩 状，充実性で典型的な褐色細胞腫の組織像に相当した。 悪性所見は認めなかった。

たこと，右腎への癒着が強固であったこと，右水堅を きたし右腎機能低下に陥っていたことより右腎を合併 切除した。 術中の血圧コントロールのため右腎静脈, 右腎動脈を最初に結梷処理してから脱転操作八入つ た，右副腎は大部分を温存し腫湟を摘出した。

出血量は4,986ccであったが回収自己血輸血装置 (セルセーバー®)で，2，100cc 返血した．回収自己血 は腫場摘出前より緩徐に開始し手術終了までに全て返 血した. 腫浧摘出前はしばしば収縮期血圧が最高200 $\mathrm{mmHg}$ 以上に上昇しニトロプルシドの間欠的投与を 必要とした．腫瘍摘出前に回収自己血輸血を開始した が同様に異常高血圧を間欠的にきたす状態が持続し た。腫場摘出後も同様のペースで自己血輸血を継続し たがニトロプルシドナトリウムなどの降圧剤, カテコ ラミンなどの昇圧剤は必要とせず収縮期血圧は150 
mmHg 以下で安定した循環動態を示した。術中の血圧 の変動を図に示す(図 2)。同種血輸血は行わなかった が手術終了時 $\mathrm{Hb} 12.2 \mathrm{~g} / \mathrm{dl}$ であった。

病理標本所見：右㱟内側に接して $13 \times 7.2 \times 5 \mathrm{~cm}$ の境界明瞭な腫湢が存在した，重量は270gであった。 表面は比較的平滑で割面は褐色, 分葉状であった（図 3 ).腫場組織は胞巣状, 充実性で典型的な褐色細胞腫 の組織像に相当した(図4)。被膜は部分的にはっきり しない部分があったが腫韵自体は境界明暸で右贸への 漫润は認めず悪性所見は認めなかった。

術後経過：術後降圧剂内服を中止するも血圧110/64 $\mathrm{mmHg}$ (退院前) と正常範讲内であった。術後経過良 好につき 11 pod 退院となった。術後 5 力月現在再発を 認めていない。

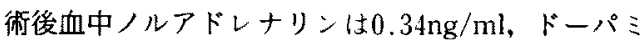
ンは $0.02 \mathrm{ng} / \mathrm{ml}$ といずれも基準值内となった。房細 動についてはワーファリンコントロール下に除細動を 行い,一時的に洞調律に回復したものの現在心房細動 の再発を認め治療中である。また，術前高值であった CEA は5.4ng/mlにまで低下したが，依然として軽度 高値を示しており多発性内分泌腺腫症 II 型（multiple endocrine neoplasia type II ; MEN type II) の合併 がないか，外来で定期的に検查を紇続している。

\section{考 察}

副腎外褐色細胞腫は傍神経節を発生母地とする腫湟 でアドレナリン，ノルアドレナリンを産生，放出する ことで知られている"。我が国の厚生省特定疾患「副腎 ホルモン産生異常症」調査研究班の報告によれば褐色 細胞腫のうち副腎外に発生するものは全体 $18.2^{\circ}$ 。 とさ れており，そのうち腎周辺部に発生するものは副腎外 褐色細胞腫全体の $16^{\circ}{ }_{0}$ とされている 中で $200 \mathrm{~g}$ を越えるものは約 $15^{\circ}{ }_{0}$ と比䡆的稀である ${ }^{3 !}$.

本症例では腫瘍か巨大で大血管と接するうえ，流入 動脈, 流出静脈が多数存在し, 右腎動脈と右腎静脈に 挟まれるような複雑な位圆関係であったために相当量 の出血が見込まれた。そのため手術開始時より回収自 己血輸血装置（セルセーバーツ）を使用した：その結 果,出血量洨4,986cc と多量であったが2,100cc の自己 血を返血することにより無輸血で手術を遂行可能であ った，腫瘍摘出前には自己血輸血の有無に関放す，

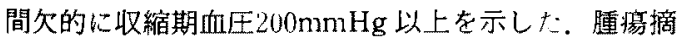
出後の安定した循環動態を考えると，腫㰾摘出前の血 圧上昇は腫浯への機械的刺激によるカデラミン放出 による影響が強いと考えられる。しかし加藤ら゙恃褐
色細胞腫手術中の回収自己血中のカテコラミンにより 血圧上昇をきたす可能性を指摘しており，特に腫韵摘 出前の自己血輸血は慎重に行うべきである，回収自己 血輸血は腫濝摘出後の循環動態の安定した段階で行う ことが望ましいと考えられるが，本症例でも腫場摘出 後の回収自己血輸血は収縮期圧 $150 \mathrm{mmHg}$ 以下の非常 に安定した循環動態のなか施行可能であった。

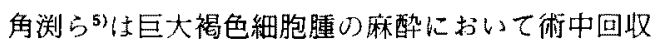
血中の力テコラミン濃度を測定し, $1,000 \mathrm{ml}$ の生理食 塩液による1回の洗浄でアドレナリンは約 $10{ }^{\circ}{ }_{0}$, ノル アドレナリンは約 $5 \%$ 。，ドーパミンは約け10。希积き れたと報告している。またドーパミン值を希釈によつ て充分に下げられないことから, 褐色細胞腫摘出術に おいて回収自己血輸血仗紫琹とまでは言えないもの 》, 自己血輸血時には血圧変動に充分注意する必要が あると結論づけている．本症例のように術前ドーパミ ン值が高值を示す場合には特に注意が必要であろう が、術前ドーパミン值が本症例と同様もしくはそれ以 下である場合には回収自己血輸血は比較的安全に施行 可能々考えられる．術前ドーパミン值がさらに異常高 值を認めるような場合には返血時の血圧上昇の危険が 高くなると考えられるが，基準となるドーパミン值な どは定まっておらず今後の症例の集積が待たれる。

副腎原発褐色細胞腫では約 $10^{\circ}{ }_{0}$ の症例で悪性を示す と言われているが，副腎外褐色細胞腫では29〜4100が 悪性所見を示すとされている゙。. 本症例では術前の画 像所見上り悪性の可能性は小さいと判断し回収自己血 輸血を行ったが，墨性の可能性が高いと判断される場 合には回収自己血輸血の適応からは除外されるべきで あこ。

\section{結語}

褐色細胞腫摘出術に際しての自己血輸血は回収自己 血中のカテコラミンによる血圧上昇が危惧されるか， 患者にとって同種血輸血を避けることは大きなメリッ トがある. 術前ドーパミン值に留意し, 術中注意深く 血圧をモニターすることて腫瘍摘出後の回収自己血輸 血は安全に行いうると考えられた。

\section{文献}

1) 佐藤辰男：副腎外蝎色細胞腫(パラガングリオー マ). 別冊日本臨林, 領域別症邹群シリース，1， 内分泌症候群, 日本臨特社, 大阪, 1993, p526529

2) 竹田亮祐, 宮侅 勇, 安原秀一郎他：褐色細胞婳 の全国集計。厚生省特定疾患「副緊ホルモン産生 
異常症」調査研究班，昭和60年度報告書、1986， p $6-25$

3）佐藤辰男：褐色細胞缰。別冊日本臨牀，領域別症 候群シリー\%，1，内分泌症候群，日本臨牀社， 大阪, $1993, \mathrm{p} 431434$

4) 加藤洋海, 近藤洞夫, 山本拓巳 他：褐色細胞腫摘 出術に㧍ける回収血中のカテコラミン濃度。麻酔
$41: 992-994,1992$

5）角㴊浩央, 加藤洋海, 土肥修司他：巨大禓色紐胞 腫摘出街における回収血中のカテコラミン濃度。 麻醉 $44: 256-259,1995$

6) Whalen RK, Althausen AF, Daniels GH : Extra -Adrenal Pheochromocytoma. J Urol $147: 1-$ 10,1992

\title{
A CASE OF GIANT EXTRAADRENAL PHEOCHROMOCYTOMA USING INTRAOPERATIVE AUTOLOGOUS BLOOD TRANSFUSION
}

\author{
Kenichi NAKAMURA, Atsuo TOKUKA and Nobuhiro OZAKI \\ Department of Surgery, Shimane Prefectural Central Hospital
}

During surgery for giant extraadrenal pheochromocytoma, it is necessary to control blood pressure and anticipate unexpected bleeding. A 51-year-old man who had an episode of hypertension and atrial fibrillation 15 years earlier was found in ultrasonography to have a giant abdominal nodule diagnosed as extraadrenal pheochromocytoma. The tumor was resected with the right kidney. Intraoperative blood loss was $4986 \mathrm{cc}$ and $2100 \mathrm{cc}$ of collected autologous blood transfused intraoperatively. Autotranfusion was begun before tumor removal and continued until the end of the operation. Blood pressure changed sharply before removal but was stable after removal. The resected specimen was $13 \times 7.2 \times 5 \mathrm{~cm}$ and benign. Intraoperative collected autologous blood transfusion contains some catecholamine and tends to elevate the blood pressure in pheochromocytoma, but careful monitoring hemodynamic changes and the preoperative rate of dopamine ensures a safe result. 